\title{
CARBON DIOXIDE EMISSIONS AT THE UKRAINIAN PULVERIZED-COAL THERMAL POWER PLANTS
}

\author{
I. Volchyn, L. Haponych \\ National University of Food Technologies
}

\begin{tabular}{l}
$\quad$ Key words: \\
Power industry \\
Environment \\
Thermal power plant \\
Flue gases \\
Carbon dioxide \\
Coefficient of carbon \\
emission \\
Coal calorific value \\
\hline
\end{tabular}

Article history:

Received 12.11.2018

Received in revised form

27.11.2018

Accepted 14.12.2018

Corresponding author:

I. Volchyn

E-mail:

npnuht@ukr.net
ABSTRACT

During the last years, changes in the world power generation envisioned a new direction of the development of consolidated power system of Ukraine, namely, the struggle against increase in the greenhouse effect, including the reduction of carbon dioxide emissions. Ukrainian power engineers should solve the problem of passage to the trajectory of low-carbon development according to the European environmental legislation and national interests. The strategy of measures for decrease in $\mathrm{CO}_{2}$ emissions in power generation should lie in the wide introduction of ecologically pure power efficient low-carbon technologies.

Ukraine signed and ratified the Agreement on association with the EU in 2014. One of the requirements advanced in this Agreement lies in establishing the procedures of monitoring, reporting, and verification (MRV) of the emissions of greenhouse gases from power plants. The system of monitoring, reporting, and verification of the emissions of greenhouse gases should be based on the assemblage of procedures for estimating the emissions of greenhouse gases.

Nowadays, Ukrainian power engineering has no common obligatory procedure for the calculation of $\mathrm{CO}_{2}$ emissions, based on using the coefficient of emissions that takes into account the fuel calorific value, which is required by the Directive 2003/87/EU. We have developed an engineering method for calculating $\mathrm{CO}_{2}$ emissions, formed during coal firing at thermal power plants. Our method is based on the specific parameters of carbon emission with regard for the low calorific value of coal. By this method, we determined the specific parameters of carbon emission and gross $\mathrm{CO}_{2}$ emissions at Ukrainian power plants during the last years. Gross $\mathrm{CO}_{2}$ emissions were 54 $106 \mathrm{t}$ in 2015 and $59 \cdot 106 \mathrm{t}$ in 2016. The specific $\mathrm{CO}_{2}$ emissions are equal to $1.1 \mathrm{t} \mathrm{CO}_{2}$ per $\mathrm{kWh}$, that is, the reduction of specific emissions of $\mathrm{CO}_{2}$ did not occur. This correlates with high specific consumptions of standard fuel at Ukrainian thermal power plants during the last years.

DOI: $10.24263 / 2225-2924-2018-24-6-17$ 


\title{
ВИКИДИ ДІОКСИДУ ВУГЛЕЦЮ НА УКРАЇНСЬКИХ ВУГІЛЬНИХ ТЕПЛОВИХ ЕЛЕКТРОСТАНЦІЯХ
}

\author{
І.А. Вольчин, Л.С. Гапонич \\ Національний університет харчових технологій
}

Останні роки у світовій енергетиці відбулися зміни, щяо зумовили новий напрям розвитку об'єднаної енергетичної системи України - ие боротьба з посиленням «парникового ефекту», в тому числі скорочення викидів діоксиду вуглецю. Перед енергетиками Украӥни стоїть завдання переходу на шлях низьковуглечевого розвитку відповідно до європейського екологічного законодавства та національних інтересів. Стратегія заходів зі зменшення викидів $\mathrm{CO}_{2}$ в енергетиці має полягати у широкому впровадження екологічно чистих енергоефективних і низьковуглечевих технологій.

Україна в 2014 р. підписала та ратифікувала Угоду про асоиіаиію з $Є C$. Однією з вимог, що висуваються в Угоді, є встановлення прочедур моніторингу, звітності та верифікачії викидів парникових газів від енергетичних установок. Основою системи моніторингу, звітності та верифікаиії викидів парникових газів є сукупність методик для оцінки викидів парникових газів. На сьогодні в енергетиці Украӥни немає єдиної обов'язкової методики розрахунку викидів $\mathrm{CO}_{2}$, яка б базувалася на використанні коефіцієнта викидів, щзо враховує теплоту згоряння палива, як того вимагає Директива 2003/87/СС.

При виконанні дослідження було створено інженерний метод розрахунку емісії $\mathrm{CO}_{2}$, що утворюється при спалюванні вугілля на TEC, на основі специфічних показників емісії вуглечю з урахуванням нижчої теплоти згоряння вугілля. За розробленим методом були отримані значення специфічних показників емісії вуглецю та валових викидів $\mathrm{CO}_{2}$ на ТЕС України в останні роки. Валові викиди вуглекислого газу у 2015 р. становили 54215,4 тис. тонн, а у 2016 p. - 59730,3 тис. тонн. Значення питомих викидів $\mathrm{CO}_{2}$ на ТЕС находяться на рівні $1,1 \mathrm{mCO} / \kappa B m 2$, тобто зменшення питомих викидів $\mathrm{CO}_{2}$ не відбулося. Це корелює з високими питомими витратами умовного палива на TЕС Украйни в останні роки.

Ключові слова: енергетика, екологія, теплова електростанція, димові гази, діоксид вуглеию, коефіиієнт емісії вуглецю, теплота згоряння вугілля.

Постановка проблеми. Останні роки у світовій енергетиці відбулися зміни, що зумовили нові напрями розвитку об'єднаної енергетичної системи України. Одним із трендів розвитку світової енергетики сьогодні є боротьба 3 посиленням «парникового ефекту», в тому числі скорочення промислових викидів вуглецю. Тому перед енергетиками України стоїть завдання - перехід на шлях низьковуглецевого розвитку енергетики відповідно до європейського екологічного законодавства та національних інтересів. Заходи зі зменшення парникового ефекту в енергетиці мають полягати у скорочення використання викопних джерел енергії - вугілля, нафти, газу та широкому 
впровадженні екологічно чистих енергоефективних і низьковуглецевих технологій [1].

У Парижі 30.11.2015-12.12.2015 пройшла XXI Конференція Сторін Рамкової конвенції ООН про зміну клімату за участю 196 країн світу, де було прийнято глобальну угоду з протидії зміні клімату на $2021-2030$ pp. - Паризьку угоду. Угода була відкрита до підписання та ратифікації з 22.04.2016 . В той же день Паризьку угоду було підписано Україною, а 13.07.2016 ратифіковано Законом України № 0105 «Про ратифікацію Паризької угоди щодо боротьби зі зміною клімату». Угода регулює процес викидів семи парникових газів: вуглекислого газу $\mathrm{CO}_{2}$, метану $\mathrm{CH}_{4}$, оксиду азоту $\mathrm{N}_{2} \mathrm{O}$, гідрофторвуглеводів, перфторвуглецю, гексафториду сірки $\mathrm{SF}_{6}$ і трифториду азоту $\mathrm{NF}_{3}$.

Згідно з Угодою, Україна сама має визначити для себе зобов'язання щодо рівня викидів парникових газів 3 урахуванням іiі соціально-економічного розвитку та фінансових можливостей і повинна переглядати їх раз на п'ять років. 30.09.2015 Україною було подано до Секретаріату Рамкової конвенції зміни клімату ООН зобов'язання, що очікуваний рівень викидів парникових газів у 2030 р. не має перевищувати $60 \%$ рівня 1990 р. — 947,3 млн т $\mathrm{CO}_{2}$ екв., тобто бути не більше 568,4 млн т $\mathrm{CO}_{2}$ екв. в рік. В Україні в останні роки об'єм викидів парникових газів скоротився [2]. У 2015 р. він був 319,0 млн т $\mathrm{CO}_{2}$ екв., тобто зменшився порівняно з 1990 р. на 66,3\%. Таке скорочення, в основному, $\epsilon$ наслідком зменшення використання енергетичних ресурсів через спад промисловості, зниження чисельності населення і попиту на електроенергію. У 2016 р. сумарні викиди парникових газів в Україні становили 338,6 млн т $\mathrm{CO}_{2}$ екв. Якщо порівняти 31990 р., сумарні викиди скоротилися на 64,2\%, але проти 2015 р. викиди збільшилися на 6,1\%. Тому поданий рівень зобов'язань скорочення викидів парникових газів є низьким і дає країні можливість їх збільшувати, що не відповідає головній меті Паризької угоди та Стратегії низьковуглецевого розвитку України [1].

Верховна Рада України та Європейський парламент 16.09.2014 синхронно ратифікували Угоду про асоціацію між Україною, з однієї сторони, та ЄС, Свропейським співтовариством 3 атомної енергії і їхніми державами-членами, з іншої сторони. Угода набрала чинності 01.09.2017. В Угоді про асоціацію сферу охорони навколишнього середовища названо однією з пріоритетних. Однією з вимог, що висуваються в Угоді, є встановлення процедур моніторингу, звітності та верифікації (MRV) викидів парникових газів від енергетичних і промислових установок [3].

Законодавство України в сфері моніторингу, звітності та верифікації викидів парникових газів знаходиться на стадії розробки за принципами: максимально можливе наближення до законодавства $Є$, врахування українських національних особливостей, ефективне залучення всіх зацікавлених сторін до процесу розроблення законодавчих актів. Відповідно до цього розроблено багаторівневу структуру актів щодо моніторингу, звітності та верифікації. Розпорядженням Кабінету Міністрів України від 07.12.2016 № 932-р схвалено «Концепцію реалізації державної політики у сфері зміни клімату на період до 2030 року» [4]. Це перший національний документ у сфері боротьби зі зміною 
клімату, у якому враховано основні положення Паризької угоди. Вже готові проект Закону України «Про засади моніторингу, звітності та верифікації та викидів парникових газів» та проект постанови Кабінету Міністрів України «Про затвердження порядку здійснення моніторингу та звітності викидів парникових газів».

Закон «Про засади моніторингу, звітності та верифікації та викидів парникових газів»є рамочним, він визначає правові та організаційні основи функціонування моніторингу, звітності та верифікації викидів парникових газів i спрямований на виконання зобов'язань України за Угодою про асоціацію між Україною та СС, з іншої сторони, а також на виконання вимог Рамкової конвенції Організації Об’єднаних Націй про зміну клімату та Паризької угоди.

Основою системи моніторингу, звітності та верифікації викидів парникових газів є сукупність методик для оцінки викидів парникових газів на рівні установок (джерел викиду). На сьогодні в енергетиці України немає єдиної обов'язкової методики розрахунку викидів парникових газів, яка б базувалася на використанні коефіцієнта викиду, що враховує теплоту згоряння вугілля, як того вимагає Директива 2003/87/СС [5].

Крім того, Мінприроди України в 2018 р. планує ввести новий вуглецевий податок, який буде виділений із структури чинного екологічного податку. Плануються певні законодавчі зміни в Податковому і Бюджетному кодексах. Міністерством оприлюднена інформація, що розмір податку буде на рівні одного євро за тонну $\mathrm{CO}_{2}$. Сьогодні в Україні в структурі екологічного податку закладено лише 0,013 євро $\left(0,41\right.$ грн) за тонну $\mathrm{CO}_{2}$. Треба зазначити, що ставка вуглецевого податку в країнах СС коливається від 5 до 130 євро за тонну і в середньому становить $15-20$ євро/т. Введення екологічного вуглецевого податку неминуче вплине на кінцеві тарифи на електричну енергію для споживачів, при ставці податку 1 євро - плата за електроенергію збільшиться на $10-15 \%$.

Суттєві викиди парникових газів в Україні відбуваються в секторі «Виробництво електроенергії та теплоти». До цієї категорії відносяться викиди від спалювання палива при виробництві електроенергії й теплоти тепловими електростанціями (ТЕС), теплоелектроцентралями (ТЕЦ), котельними тощо. У 1990 -2016 рр. на них припадало 26,7 - 34,7\% від загальної емісії парникових газів в Україні. Зниження викидів у секторі «Виробництво електроенергії та теплоти» в 2016 р. порівняно з 1990 р. становить 64,8\%, з 272,7 до 95,9 млн. т $\mathrm{CO}_{2}$ екв. Найбільшим джерелом емісії парникових газів в енергетиці є вугільні теплові електростанції, де у період 1990-2016 рр. викидалося $13-19 \%$ від загального обсягу викидів парникових газів. Основний парниковий газ, що утворюється при спалюванні органічного палива на TEC, - це діоксин вуглецю.

В останні роки в паливному балансі ТЕС частка вугілля є переважною. Вона становить 98\%, а частка природного газу та мазуту, які використовуються для пуску вугільних котлів, відповідно, - 2\% [6; 7]. При спалюванні природного газу та мазуту утворюється всього $1,5-2,0 \%$ від загального об’єму димових газів ТЕС. Головні фактори, що визначають величезні об’єми викидів діоксиду вуглецю на ТЕС — це обсяги споживання вугілля та високі 
витрати палива на виробництво електроенергії. Тому стратегія боротьби 3 зменшенням викидів $\mathrm{CO}_{2}$ в енергетиці має полягати у широкому впровадження енергоефективних, енергоощадних екологічно чистих і низьковуглецевих технологій, в тому числі підвищенні ефективності переробки вугілля.

Загальний обсяг видобутку вугілля на шахтах України у 2016 р. становив 40,9 млн. т, 3 них 32,5 млн т - це енергетичне вугілля, в 2017 р. було видобуто 34,9 млн. т, 3 них енергетичного - 31,0 млн т. В останні роки на українських ТЕС щорічно споживається 25-30 млн т вугілля. Тому становить інтерес питання розрахунку викидів вуглекислого газу, що утворюються саме при спалюванні вугілля на ТЕС.

При відомому елементному складі вугілля, що постачається на ТЕС, за стандартною методикою [8-10] можна визначити кількість діоксиду вуглецю в сухих димових газах, що утворилася при спалюванні вугілля. Але в реальних умовах партії вугілля, що постачаються на ТЕС, супроводжуються тільки технічним аналізом. Тому метою дослідження $\epsilon$ створення інженерного методу розрахунку емісії $\mathrm{CO}_{2}$, що утворюється при спалюванні вугілля на TEC, за даними технічного аналізу з обов'язковим урахуванням нижчої теплоти згоряння палива на робочий стан палива $Q_{i}^{r}$, як того вимагає Директива 2003/87/€С.

Викладення основних результатів дослідження. Розрахунок емісії діоксиду вуглецю на ТЕС може виконуватися на основі постійних неперервних вимірювань концентрацій $\mathrm{CO}_{2}$ та об'ємної витрати димових газів або розрахункових методів за даними про витрати та склад використаного палива i характеристики енергетичних котлів [8-10]. Для організації постійних неперервних вимірювань концентрацій забруднювальних речовин та об'ємної витрати димових газах потрібно використовувати вимірювальне обладнання, якого сьогодні немає на ТЕС України.

Розрахункові методи визначення викиду $\mathrm{CO}_{2}$, що утворюються при спалюванні вугілля, базуються на використанні коефіцієнта викиду (показника емісії, emission factoe) та ступеня окислення вуглецю палива в котлі:

$$
E_{\mathrm{CO}_{2}}=10^{-6} k_{\mathrm{CO}_{2}} \cdot B \cdot Q_{i}^{r},
$$

де $E_{\mathrm{CO}_{2}}$ - валовий викид $\mathrm{CO}_{2}$, тис. т; $k_{\mathrm{CO}_{2}}$ - коефіцієнт викиду $\mathrm{CO}_{2}$, г/ГДж; $Q_{i}^{r}$ - нижча робоча теплота згоряння вугілля, МДж/кг; $B-$ витрата вугілля за проміжок часу (рік), тис. т.

Коефіцієнт викиду характеризує масову кількість забруднювальної речовини, яка викидається енергетичною установкою в атмосферне повітря разом 3 димовими газами, віднесену до одиниці енергії, що виділяється при згорянні палива. Він залежить від багатьох чинників. Існують два коефіцієнти викиду узагальнений і специфічний. При наявності обох коефіцієнтів необхідно використовувати специфічний.

Узагальнений коефіцієнт викиду є середньою питомою величиною викиду для певної категорії енергетичних установок, певної технології спалювання палива, певного виду палива з урахуванням заходів щодо зниження викиду 
забруднювальної речовини. Він не враховує особливостей хімічного складу палива.

Специфічний коефіцієнт викиду є питомою величиною викиду, яка визначається для конкретної енергетичної установки з урахуванням індивідуальних характеристик палива, конкретних характеристик процесу спалювання та заходів щодо зниження викиду забруднювальної речовини. Специфічний коефіцієнт викиду $\mathrm{CO}_{2}$ для вугілля можна записати [8]:

$$
k_{\mathrm{CO}_{2}}=\frac{44}{12} \cdot \frac{C^{r}}{100} \cdot \frac{10^{6}}{Q_{i}^{r}} \varepsilon_{C}=3,67 k_{C} \varepsilon_{C},
$$

де $C^{r}$ - масовий вміст вуглецю в вугіллі на робочу масу, \%; $Q_{i}^{r}-$ нижча робоча теплота згоряння вугілля, МДж/кг; $\varepsilon_{C}-$ ступінь окислення вуглецю палива; $k_{\mathrm{C}}$ - коефіцієнт викиду вуглецю палива, г/ГДж.

Ступінь окислення вуглецю $\varepsilon_{C}$ палива визначається за формулою [8]:

$$
\varepsilon_{C}=1-\frac{A^{r}}{C^{r}}\left(a_{\text {вин }} \frac{\Gamma_{\text {вин }}}{100-\Gamma_{\text {вин }}}+\left(1-a_{\text {шлл }}\right) \frac{\Gamma_{\text {шл }}}{100-\Gamma_{\text {шл }}}\right)=1-\frac{q^{r}}{C^{r}} \cdot \frac{Q_{i}^{r}}{Q_{C}}, \text { (3) }
$$

де $q_{4}$ - втрати теплоти через механічний недопал, $\%$; $Q_{C}$ - теплота згоряння вуглецю до $\mathrm{CO}_{2}$, яка дорівнює 32,68 МДж/кг;

Ступінь окислення вуглецю $\varepsilon_{C}$ палива 3 точністю до $0,6 \%$ можна визначати за формулою [11]:

$$
\varepsilon_{C}=1 /\left(1-q_{4} / 100\right) .
$$

Специфічний коефіцієнт викиду вуглецю $k_{C}$ - це відношення вмісту вуглецю вугілля до його теплоти згоряння:

$$
k_{C}=\frac{C^{r}}{100} \cdot \frac{10^{6}}{Q_{i}^{r}},
$$

де $C^{r}-$ масовий вміст вуглецю в паливі на робочу масу, \%; $Q_{i}^{r}-$ нижча робоча теплота згоряння вугілля, МДж/кг.

За відсутності даних про вміст вуглецю у вугіллі та його теплоту згоряння для оціночних розрахунків можна користуватись узагальненими коефіцієнтами викиду вуглецю $k_{C}$, г/ГДж наведеними або в національному керуючому документі ГКД 34.02.305-2002 [8], або у звіті Міжурядової групи експертів зі зміни клімату (Intergovernmental Panel on Climate Change, IPCC) [7]. 3 табл. 1 видно, що значення коефіцієнтів викиду вуглецю з національних і європейських керівництв відрізняються суттєво. В табл. 1 також наведені значення узагальнених коефіцієнтів викиду вуглецю для спалювання українського енергетичного вугілля різних марок отримані [12].

Треба зазначити, що в європейських керівних і методичних документах 3 визначення парникових газів $[9 ; 10]$ визначено, що значення специфічних коефіцієнтів викиду вуглецю та діоксиду вуглецю залежить від країни видобутку вугілля і рекомендується використовувати національні значення цих коефіцієнтів. 
Таблиия 1. Значення узагальнених коефіціснтів емісії вуглецю $\boldsymbol{k}_{\mathrm{C}}$, г/ГДж для енергетичного вугілля різних марок

\begin{tabular}{|c|c|c|c|}
\hline \multirow{2}{*}{ Вугілля } & \multicolumn{3}{|c|}{$k_{\mathrm{C}}, \Gamma / \Gamma Д ж$} \\
\cline { 2 - 4 } & {$[8]$} & {$[10]$} & {$[12]$} \\
\hline Антрацит (А) & 28160 & 26810 & 28560 \\
\hline Пісне (П) & 26050 & немає даних & 26200 \\
\hline Газове та довгополуменеве (Г, ДГ) & 25180 & 25800 & 25680 \\
\hline
\end{tabular}

Отже, розрахунок специфічного коефіцієнта викиду вуглецю базується на використанні вмісту вуглецю в вугіллі $C^{r}$, значеннях нижчої робочої теплоти згоряння палива $Q_{i}^{r}$ і втрат теплоти через механічний недопал палива в енергетичній установці $q_{4}$. Але в реальних умовах партії вугілля, що постачаються на ТЕС, супроводжуються технічним аналізом, у якому надані тільки такі характеристики палива, як волога на робочий стан $W_{t}^{r}$, зольність $A^{d}$ та сірка $S^{d}$ на сухий стан, нижча теплота згоряння вугілля $Q_{i}^{r}$ на робочий стан палива. Дані технічного аналізу не дають змоги безпосередньо (за стандартною методикою) розрахувати специфічні показник емісії вуглецю для вугілля та емісію діоксиду вуглецю. Тому нами було розроблено метод розрахунку специфічного показник емісії вуглецю для енергетичного вугілля різних марок.

Розрахунки виконані за даними 140 сертифікатів на вугільну продукцію 3 шахт і збагачувальних фабрик Донецького вугільного басейну, для зразків вугілля марок А, П, Г, ДГ, Д, з діапазоном $Q_{i}^{r}$ від 16,1 до 31,3 МДж/кг. Сертифікати складено та затверджено державним підприємством «УкрНДІвуглезбагачення», м. Дніпро. На основі цих сертифікатів було визначено елементний склад для кожного зразка палива. В сертифікаті, зокрема, визначено такі характеристики, як марка вугілля, вміст летких на сухий беззольний стан (горючу масу) $V^{d a f}$, зольність на сухий стан $A^{d}$, загальна сірка на сухий стан $S_{t}^{d}$, вища теплота згоряння на сухий беззольний стан $Q_{s}^{d a f}$, загальна волога на робочий стан $W_{t}^{r}$, піритна сірка на сухий стан $S_{p}{ }^{d}$, сульфатна сірка на сухий стан $S_{s}^{d}$, нижча теплота згоряння на робочий стан $Q_{i}^{r}$, органічний вуглець на сухий беззольний стан $C^{d a f}$, органічний водень на сухий беззольний стан $H^{d a f}$, органічна сірка на сухий беззольний стан $S_{o}^{d a f}$, азот і кисень на сухий беззольний стан $(N+O)^{d a f}$ тощо. Тобто за даними сертифікатів було проведено розрахунки за формулами (2)-(5).

На рис. 1 наведено результати розрахунків специфічних коефіцієнтів викиду вуглецю вугілля $k_{\mathrm{C}}$ для 140 зразків енергетичного вугілля України різних марок, а саме: А, Т, Г та ДГ. Встановлено, що для вугілля марок А, Г та ДГ залежність специфічних показників емісії вуглецю вугілля $k_{\mathrm{C}}$, $/$ ГДж від теплоти згоряння вугілля $Q_{i}^{r}$, МДж/кг, має лінійний характер: $k_{C}=A-b \cdot Q_{i}^{r}$, де $a$ та $в-$ коефіцієнти, що залежить від марки вугілля. Для вугілля марки П залежності специфічних коефіцієнтів емісії вуглецю вугілля від теплоти згоряння палива не виявлено.

У табл. 2 наведено узагальнені результати розрахунків залежності значень специфічних коефіцієнтів емісії вуглецю $k_{\mathrm{C}}$ від нижчої теплоти згоряння вугілля $Q_{i}^{r}$, середнє квадратичне відхилення $\sigma$, діапазон отриманих значень 
специфічних коефіцієнтів емісії вуглецю та значення узагальнених коефіцієнтів емісії вуглецю для вугілля марок А, П, Г та ДГ.

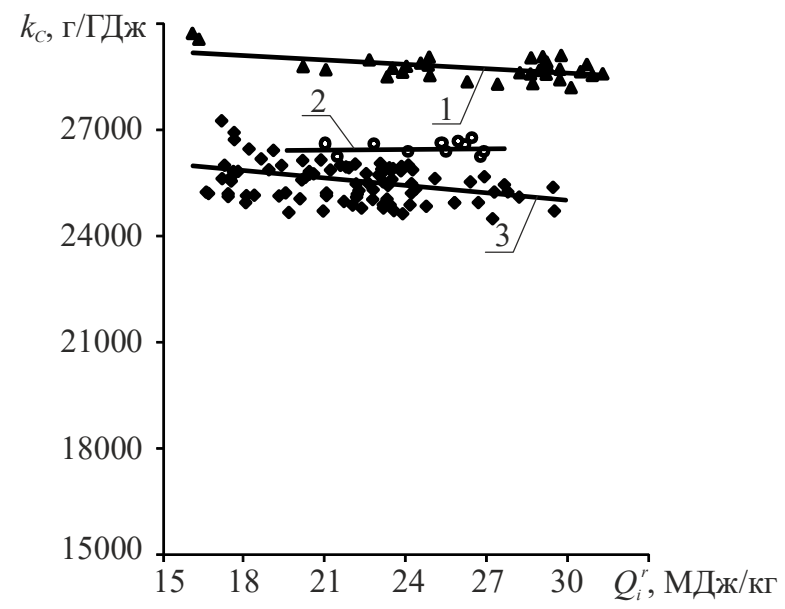

Рис. 1. Залежності специфічних коефіціснтів емісії вуглецю вугілля $\boldsymbol{k}_{\mathrm{C}}$ від теплоти згоряння вугілля $Q_{i}^{r}$ для зразків енергетичного вугілля України марок А, Т, $\Gamma$ та ДГ:

1 - марка A; 2 - марка T; 3 - марки Д та ДГ

Таблиця 2. Специфічні та узагальнені коефіціснти емісії вуглецю для енергетичного вугілля України різних марок

\begin{tabular}{|c|c|c|c|}
\hline Коефіцієнт емісії & \multicolumn{3}{|c|}{ Для вугілля марок } \\
\cline { 2 - 4 } вуглецю $k_{\mathrm{C}}$, г/ГДж & $\mathrm{A}$ & $\Pi$ & Д та ДГ \\
\hline Специфічний: & & & \\
залежність & $k_{C}=29900-40 \cdot Q_{i}^{r}$ & 26450 & $k_{C}=26800-55 \cdot Q_{i}^{r}$ \\
$\sigma, \%$ & 0,97 & 0,90 & 2,39 \\
макс. значення & 29735 & 26805 & 27292 \\
мін. значення & 28200 & 25934 & 24116 \\
\hline Узагальнений & 28760 & 26450 & 25630 \\
\hline
\end{tabular}

Аналіз результатів показує, що значення узагальнених коефіцієнтів викиду вуглецю з різних літературних джерел (табл. 1) знаходяться в діапазоні значень, отриманих 3 розрахунків специфічних коефіцієнтів емісії вуглецю (табл. 2, наведено максимальні та мінімальні значення). Похибка розрахунку специфічного коефіцієнта емісії вуглецю за залежностями, наведеними в табл. 2, не перевищує 2,5\%, що відповідає вимогам до моніторингу, звітності та верифікації викидів парникових газів від енергетичних і промислових установок $[9 ; 10]$. Треба зазначити, що на ТЕС України спалюються паливні суміші з низькорекційного вугілля марок А, П. Використання значень узагальнених коефіцієнтів викиду вуглецю вугілля 3 табл. 1 та 2 пов'язано 3 деякими похибками, оскільки в офіційній звітності ТЕС не надається інформація $з$ масових часток вугілля тієї чи іншої марки. Тому для оціночних розрахунків специфічних показників емісії вуглецю при спалюванні сумішей вугілля марок А та П пропонується використовувати залежність $k_{C}=28900-$ 
$50 \cdot Q_{i}^{r}$, середнє квадратичне відхилення в цьому випадку складає $\sigma=4,4 \%$. Враховуючи практичне значення методики розрахунку коефіцієнтів емісії вуглецю у випадку спалювання сумішей вугілля марок А та П, планується продовження робіт в цьому напрямку для залучення більшої інформації 3 елементного складу зразків вугілля марки П.

За залежностями специфічних коефіцієнтів викиду вуглецю з урахуванням нижчої теплоти згоряння вугілля (табл. 2) та формулою (4) для розрахунку степенів окислення вуглецю були проведені розрахунки специфічних показників викиду вуглецю та валових викидів діоксиду вуглецю на ТЕС України. Для розрахунків використовувалася інформація 3 якості, витрати вугілля, що постачалося на ТЕС, та $q_{4} 3$ офіційних звітів ТЕС-3ТЕх. В табл. 3 наведено результати розрахунків для вугільних ТЕС та п'яти генеруючих компаній України для 2016 року. В табл. 3 також показані марки палива, що спалюються на ТЕС.

Таблиця 3. Специфічні коефіціснти емісії вуглецю та валові викиди $\mathrm{CO}_{2}$ від спалювання вугілля на ТЕС України у 2016 році

\begin{tabular}{|c|c|c|c|c|c|c|c|c|}
\hline \multirow{3}{*}{$\begin{array}{c}\text { Генеруюча компанія / } \\
\text { TEC }\end{array}$} & \multirow{3}{*}{ 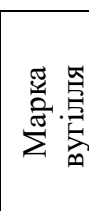 } & \multicolumn{2}{|c|}{ Вугілля } & \multirow{3}{*}{$q_{4}, \%$} & \multicolumn{4}{|c|}{ Розрахунок } \\
\hline & & 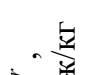 & & & \multicolumn{2}{|c|}{$\begin{array}{c}\text { урахуванням } Q_{i}^{r} \\
\text { та } q_{4} \\
\end{array}$} & \multicolumn{2}{|c|}{$\begin{array}{c}\text { за [5] } 3 \\
\text { урахуванням } q_{4}\end{array}$} \\
\hline & & の & тис. тон & & $\begin{array}{c}k_{c} \\
\text { г/ГДж }\end{array}$ & \begin{tabular}{|c|}
$E_{\mathrm{CO}_{2}}$ \\
тис. тонн
\end{tabular} & $\begin{array}{c}k_{c}, \\
\text { г/ГДж }\end{array}$ & $\begin{array}{c}E_{\mathrm{CO}_{2}} \\
\text { тис. тонH }\end{array}$ \\
\hline 1 & 2 & 3 & 4 & 5 & 6 & 7 & 8 & \\
\hline ДОНБАСЕНЕРГО & & & 4009,7 & & & 9344,7 & & 9112,0 \\
\hline Старобешівська ТЕС & $\mathrm{A}, \Pi$ & 23,30 & 2449,7 & 3,73 & 27735 & 5586,9 & 27100 & 5459,0 \\
\hline Слов'янська ТЕС & A & 23,30 & 1560,0 & 2,68 & 28968 & 3757,8 & 28160 & 3653,0 \\
\hline ЦЕНТРЕНЕРГО & & & 5041,8 & & & 10685,0 & & 10473,0 \\
\hline Вуглегірська ТЕС & $\Gamma, Д \Gamma$ & 22,35 & 2521,3 & 0,21 & 25571 & 5273,2 & 25180 & 5192,6 \\
\hline Трипільська ТЕС & $\mathrm{A}, \Pi$ & 21,93 & 1433,7 & 6,18 & 27804 & 3007,3 & 27100 & 2931,2 \\
\hline Зміївська ТЕС, в т. ч. & \multirow{4}{*}{ А, П } & 23,23 & 1086,70 & & & 2404,5 & 27100 & 2349,2 \\
\hline ст. № $1-4$ & & 23,25 & 377,8 & 5,15 & 27738 & 846,8 & 27100 & 827,3 \\
\hline ст. № 5-6 & & 23,26 & 372,0 & 4,39 & 27737 & 841,4 & 27100 & 822,1 \\
\hline ст. № 7-10 & & 23,19 & 336,9 & 9,89 & 27740 & 716,3 & 27100 & 699,8 \\
\hline ДНІПРОЕНЕРГО & & & 6030,8 & & & 12734,0 & & 12505,2 \\
\hline Криворізька ТЕС & $\Pi$ & 24,03 & 2310,3 & 5,71 & 26450 & 5077,2 & 26050 & 5000,4 \\
\hline $\begin{array}{l}\text { Придніпровська ТЕС, } \\
\text { в т. ч. }\end{array}$ & \multirow{3}{*}{ А, П } & 2. & 1354,9 & & & 999,2 & 27100 & 2931,4 \\
\hline ст. № $7-10$ & & 23,46 & 986,4 & 7,05 & 27727 & 2187,7 & 27100 & 2137,2 \\
\hline ст. № $11-14$ & & 23,50 & 368,5 & 7,73 & 27725 & 812,5 & 27100 & 794,2 \\
\hline Запорізька ТЕС & $\Gamma, Д Г$ & 21,02 & 2365,6 & 0,39 & 25644 & 4657,6 & 25180 & 4573,4 \\
\hline ЗАХІДЕНЕРГО & & & 7580,3 & & & 14701,2 & & 14429,5 \\
\hline Бурштинська ТЕС & $\Gamma, Д Г$ & 20,74 & 4234,0 & 1,26 & 25659 & 8158,3 & 25180 & 8006,0 \\
\hline $\begin{array}{l}\text { Добротвірська TEC, } \\
\text { в т. ч. }\end{array}$ & \multirow{3}{*}{$\Gamma$, ДГ } & 21,01 & 1164,2 & & & 2267,3 & 25180 & 3 \\
\hline ст. № 7-8 & & 21,0 & 725,2 & 1,39 & 25645 & 1412,0 & 25180 & 1386,4 \\
\hline $4 * 50 \mathrm{MBT}$ & & 21,05 & 439,0 & 1,54 & 25642 & 855,3 & 25180 & 839,9 \\
\hline Ладижинська ТЕС & $\Gamma$, ДІ & 20,91 & 2182,1 & 0,36 & 25650 & 4275,6 & 25180 & 4197,2 \\
\hline СХІДЕНЕРГО & & & 6573,6 & & & 12265,4 & & 11980,8 \\
\hline
\end{tabular}




\begin{tabular}{|c|c|c|c|c|c|c|c|c|}
\hline \multicolumn{9}{|c|}{ Продовження табл. 3} \\
\hline 1 & 2 & 3 & 4 & 5 & 6 & 7 & 8 & 9 \\
\hline Зуївська ТЕС & $\Gamma$, ДГ & 19,85 & 1775,5 & 0,25 & 25708 & 3314,5 & 25180 & 3246,4 \\
\hline Курахівська ТЕС & $\Gamma$, ДГ & 17,37 & 2896,0 & 2,17 & 25844 & 4665,1 & 25180 & 4545,1 \\
\hline Луганська ТЕС & $\mathrm{A}, \Pi$ & 23,51 & 1902,2 & 5,72 & 27725 & 4285,8 & 27100 & 4189,3 \\
\hline ВСБОГО, з них & & & 29236,2 & & & $\mathbf{5 9 7 3 0 , 3}$ & & $\mathbf{5 8 5 0 0 , 5}$ \\
\hline на АШ + П & & 23,71 & 12097,5 & & & 27118,8 & & 26513,5 \\
\hline на $\Gamma+$ Д & & 19,98 & 17138,7 & & & 32611,5 & & 31987,0 \\
\hline
\end{tabular}

Використання для розрахунків коефіцієнтів викиду вуглецю з урахуванням нижчої теплоти згоряння вугілля дали значення викидів $\mathrm{CO}_{2}$ на ТЕС України у 2016 р. на 1230 тис. тонн більше ніж при використанні методики [8]. Крім того, урахування в розрахунках нижчої теплоти згоряння вугілля відповідає вимогам до моніторингу, звітності та верифікації викидів парникових газів від енергетичних і промислових установок [9; 10].

У табл. 4 наведено узагальнені характеристики питомих викидів $\mathrm{CO}_{2}$ на вугільних ТЕС України в 2014 - 2016 роках. Результати узагальнено для ТЕС, що спалюють вугілля марок А, П, і для ТЕС, що спалюють вугілля марок $Г$, ДГ. Для розрахунків використовувалася інформація з якості, витрати вугілля, паливного балансу та відпущеної на ТЕС електроенергії з офіційних звітів TEC-3TEx.

Таблиця 4. Питомі викиди СО $\mathrm{CO}_{2}$ на ТЕС України у 2014-2016 pp.

\begin{tabular}{|c|c|c|c|c|c|c|}
\hline \multirow{2}{*}{$\begin{array}{c}\text { Вугільні ТЕС } \\
\text { України }\end{array}$} & \multirow{2}{*}{$\begin{array}{c}\text { Відпущена } \\
\text { електроенергія, } \\
\text { тис. кВтг } \\
\end{array}$} & \multicolumn{3}{|c|}{ Питомий вихід $\mathrm{CO}_{2}$} & \multirow{2}{*}{$\begin{array}{c}\text { КПД, } \\
\%\end{array}$} & \multirow{2}{*}{$\begin{array}{c}\text { Витрата } \\
\text { У. П., } \\
\text { г/кВтг }\end{array}$} \\
\hline & & $\begin{array}{c}\text { кг } \mathrm{CO}_{2} / \\
\text { кВтг }\end{array}$ & $\begin{array}{c}\text { т } \mathrm{CO}_{2} / \\
\text { т вугілля }\end{array}$ & $\begin{array}{c}\text { т CO } \mathrm{CO}_{2} / \mathrm{T} \\
\text { у. П. вугілля }\end{array}$ & & \\
\hline \multicolumn{7}{|c|}{2014 p. } \\
\hline Всього & 62032,7 & 1,1 & 2,1 & 2,76 & 31,2 & 397,7 \\
\hline на $A+\Pi$ & 28561,6 & 1,13 & 2,2 & 2,8 & 29,7 & 413,6 \\
\hline на $\Gamma+Д Г$ & 33471,0 & 1,0 & 1,9 & 2,7 & 31,2 & 387,9 \\
\hline \multicolumn{7}{|c|}{$2015 \mathrm{p}}$. \\
\hline Всього & 49397,8 & 1,1 & 2,0 & 2,8 & 30,9 & 400,8 \\
\hline на $A+\Pi$ & 15564,5 & 1,2 & 2,3 & 2,9 & 28,8 & 428,5 \\
\hline на Г+ДГ & 33833,2 & 1,0 & 1,9 & 2,7 & 31,6 & 389,8 \\
\hline \multicolumn{7}{|c|}{$2016 \mathrm{p}$} \\
\hline Всього & 52726,3 & 1,1 & 2,0 & 2,1 & 30,7 & 403,7 \\
\hline на $A+\Pi$ & 21454,9 & 1,3 & 2,2 & 2,3 & 29,1 & 423,8 \\
\hline на Г+ДГ & 31271,4 & 1,0 & 1,9 & 1,9 & 31,8 & 395,6 \\
\hline
\end{tabular}

3 табл. 4 видно, що значення питомих викидів $\mathrm{CO}_{2}$ на ТЕС находяться на рівні $1,1 \mathrm{TCO}_{2} /$ кВтг, причому на ТЕС, що спалюють вугілля марок А та П, значення находяться на рівні $1,3 \mathrm{TCO}_{2} / \mathrm{\kappa BTг,} \mathrm{тобто} \mathrm{вище} \mathrm{на} 30 \%$, ніж на ТЕС, що спалюють вугілля марок Г та ДГ. Для порівняння — на вугільних ТЕС Японії, Свропи, Америки, що працюють на надкритичних параметрах пари (тиск пари 240-260 бар, такі як вугільні ТЕС України) із встановленим обладнанням сірко- та азотоочистки, цей показник складає $0,85 \mathrm{TCO}_{2} / \kappa В т г$, а на TEC, що працюють на надсуперкритичних параметрах пари (більше 280 бар), $-0,84-0,76 \mathrm{TCO}_{2} / \mathrm{\kappa Bтг} \mathrm{[13].} \mathrm{Треба} \mathrm{зазначити,} \mathrm{що} \mathrm{в} \mathrm{базовому} 2009$ р. для 
об’єднаної енергосистеми України цей показник був 1,05 т $\mathrm{CO}_{2} /$ кВтг [14], тобто зменшення питомих викидів $\mathrm{CO}_{2}$ не відбулося. Це корелює зі зменшенням КПД вугільних блоків і збільшенням питомих витрат палива на 1 кВтг виробленої електроенергії, що спостерігається на ТЕС України в останні роки [15]. Середній ККД вугільних енергоблоків низький, він становить близько $31 \%$. При цьому спостерігаються високі питомі витрати умовного палива (у. п.) на 1 кВтгодину відпущеної електроенергії (табл. 4), у 2015 р. вони були 400,8 г/кВтг., у 2016 p. - 403,7 г/кВтг, у 2017 p. - 401,3 г/кВтг.

Отримано також значення питомих викидів $\mathrm{CO}_{2}$ на тонну спожитого вугілля. Цей показник $€$ корисним для практичних розрахунків екологічного податку.

\section{Висновки}

1. Україна підписала та ратифікувала Угоду про асоціацію між Україною та ЄС. Однією з вимог, що висуваються в Угоді, є встановлення процедур моніторингу, звітності та верифікації викидів парникових газів від енергетичних і промислових установок.

2. Основою системи моніторингу, звітності та верифікації викидів парникових газів $\epsilon$ сукупність методик для оцінки викидів парникових газів. На сьогодні в енергетиці України немає єдиної обов'язкової методики розрахунку викидів парникових газів, яка б базувалася на використанні коефіцієнта викидів парникових газів, який враховує теплоту згоряння палива, як того вимагає Директива 2003/87/ЄС.

3. При проведенні дослідження було створено інженерний метод розрахунку викиду $\mathrm{CO}_{2}$, що утворюється при спалюванні вугілля на ТЕС, на основі специфічних коефіцієнтів викиду вуглецю 3 урахуванням нижчої теплоти згоряння вугілля.

4. За розробленим методом були отримані значення специфічних коефіцієнтів викиду вуглецю та валових викидів $\mathrm{CO}_{2}$ на ТЕС України у 2014 -2016 pр. Значення питомих викидів $\mathrm{CO}_{2}$ на ТЕС находяться на рівні $1,1 \mathrm{TCO}_{2} / \mathrm{\kappa BT \Gamma}$.

5. Через необхідність роботи в маневрених режимах середній ККД вугільних енергоблоків України становить близько $31 \%$, тому в останні роки спостерігаються високі питомі витрати умовного палива, які перевищують 400 г/кВтг відпущеної електроенергії, а питомий вихід вуглекислого газу вище 1,1 кг/кВтг. Стратегія боротьби щодо зменшення викидів $\mathrm{CO}_{2}$ в енергетиці має полягати у широкому впровадження екологічно чистих енергоефективних, енергоощадних і низьковуглецевих технологій, в тому числі підвищенні ефективності використання енергії угілля.

\section{Література}

1. Проект Стратегії низьковуглецевого розвитку України до 2050 року / Міністерство екології та природних ресурсів України. 2017. 51 с.

2. Annual National Inventory Report for Submission under the United Nations Framework Convention on Climate Change and the Kyoto Protocol / Ministry of Ecology and Natural Resources of Ukraine. 2018. 519 p.

3. Угода про асоціацію між Україною, з однієї сторони, та Європейським Союзом, Європейським співтовариством 3 атомної енергії і їхніми державами-членами, 3 іншої сторони. Офіиійний вісник України. 2014. Том 1, № 75. С. 83. 
4. Розпорядження Кабінету Міністрів України від 7 грудня 2016 року № 932-р «Концепція реалізації державної політики у сфері зміни клімату на період до 2030 року». Офіџіийний вісник Украӥни. 2016. № 99. С. 269.

5. Directive 2003/87/EC of the European Parliament and of the Council of 13 October 2003 establishing a scheme for greenhouse gas emission allowance trading within the Community and amending Council Directive 96/61/EC. Official Journal. 2003. L 275. P. $32-46$.

6. Вольчин І.А., Гапонич Л.С. Розрахунок параметрів димових газів вугільних теплових електростанцій на основі характеристик твердого палива. Энерготехнологии и ресурсосбережение. 2016. № 1. С. 49-55.

7. Volchyn I., Haponych L. Engineering method for calculating the parameters of flue gas parameters of coal-fired thermal power plants based on solid fuel characteristscs. Ukrainian Journal of Food Science. 2016. Volume 4, Issue 2. P. 327-338.

8. ГКД 34.02.305 2002. «Викиди забруднюючих речовин в атмосферне повітря від енергетичних установок. Методика визначення». Київ: ОЕП «ГРІФРЕ», 2002. 42 с.

9. EMEP/EEA air pollutant emission inventory guidebook 2016. Technical guidance to prepare national emission inventories. EEA Report. 2016. No 21. 26 p.

10. Guidelines for National Greenhouse Gas Inventories. Volume 2: Energy. Chapter 2: Stationary Combustion. IPCC, 2006. 47 p.

11. Volchyn I., Haponych L. Estimate of the sulfur dioxide concentration at thermal power plants fired by donetsk coal. Power Technology and Engineering. 2014. Vol. 48, No. 3. P. 218-221.

12. Инвентаризация парниковых газов в теплоенергетике Украины: особенности проведения инвентаризации парниковых газов в теплоенергетической отрасли / Ю.П. Корчевой, И.А. Вольчин, А.М. Коломиец, Н.В. Парасюк, А.А. Потапов. Энергетика и электрификаичия. 2002. № 6. С. 46-51.

13. Phillips J.N., Wheeldon J.M. Economic Analysis of Advanced Ultra-Supercritical Pulverized Coal Power Plants: A Cost-Effective $\mathrm{CO}_{2}$ Emission Reduction Option? Proceedings from the Sixth International Conference «Advances in Materials Technology for Fossil Power Plants». Santa Fe, New Mexico, USA. 2010. P. 53-64.

14. Динамика развития коэффициентов выбросов углерода при производстве электрической энергии. Исследование базового уровня выбросов в Украине. Заключительный отчет. Европейский банк реконструкции и развития. 2010. $41 \mathrm{c}$.

15. Перспективи впровадження чистих вугільних технологій в енергетику країни / I.А. Вольчин, Н.І. Дунаєвська, Л.С. Гапонич, М.В. Чернявський, О.І. Топал, Я.І. Засядько. Київ: ГНОЗІС, 2013. 310 с. 